\title{
ANALOGY OF HYDRATED CALCIUM SILICOALUMINATES AND HEXACALCIUM ALUMINATE TO HYDRATED CAL- CIUM SULFOALUMINATES
}

\author{
By E. P. Flint and Lansing S. Wells
}

\section{ABSTRACT}

Two hydrated calcium silicoaluminates were prepared, which appear to be the silica analogs of the hydrated calcium sulfoaluminates. The low-silica compound has the formula, $3 \mathrm{CaO} . \mathrm{Al}_{2} \mathrm{O}_{3} \cdot \mathrm{CaSiO}_{3} \cdot 12 \mathrm{H}_{2} \mathrm{O}$. It occurs as hexagonal plates, is uniaxial negative, and has the indices of refraction, $\omega=1.538, \epsilon=1.523$. The other compound occurs as needle-shaped prisms and is uniaxial negative; $\omega=1.487, \epsilon=1.479$. It was not obtained in pure form but, by analogy with other calcium aluminate complex salts, was tentatively assigned the formula, $3 \mathrm{CaO}$. $\mathrm{Al}_{2} \mathrm{O}_{3} .3 \mathrm{CaSiO}_{3} .30-32 \mathrm{H}_{2} \mathrm{O}$. The low-silica compound is slowly converted to the high-silica silicoaluminate on standing in contact with lime solutions. The highsilica compound was identified in mixtures of $\beta-2 \mathrm{CaO} . \mathrm{SiO}_{2}$ and $4 \mathrm{CaO} . \mathrm{Al}_{2} \mathrm{O}_{3}$. $\mathrm{Fe}_{2} \mathrm{O}_{3} ; \beta-2 \mathrm{CaO}$. $\mathrm{SiO}_{2}$ and $3 \mathrm{CaO} . \mathrm{Al}_{2} \mathrm{O}_{3} ;$ and $3 \mathrm{CaO} . \mathrm{SiO}_{2}$ and $4 \mathrm{CaO} . \mathrm{Al}_{2} \mathrm{O}_{3} . \mathrm{Fe}_{2} \mathrm{O}_{3}$ which had stood in contact with approximately saturated lime solution for 3 years. A hydrated hexacalcium aluminate, $6 \mathrm{CaO} . \mathrm{Al}_{2} \mathrm{O}_{3} .33 \mathrm{H}_{2} \mathrm{O}$, was prepared. It occurs as long, needle-like prisms, is uniaxial negative, and $\omega=1.475, \epsilon=1.466$. Its formula may be written as $3 \mathrm{CaO} . \mathrm{Al}_{2} \mathrm{O}_{3} .3 \mathrm{Ca}(\mathrm{OH})_{2} .30 \mathrm{H}_{2} \mathrm{O}$, which indicates that it is the compound formed when the $\mathrm{CaSO}_{4}$ in the high-sulfate sulfoaluminate is completely replaced by $\mathrm{Ca}(\mathrm{OH})_{2}$.

\section{CONTENTS}

I. Introduction

II. Experimental procedure and resuits

1. Preparation of hydrated calcium silicoaluminates . . . . . .

2. Formation of high-silica calcium silicoaluminate from mixtures

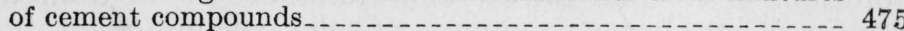

3. Preparation of hydrated hexacalcium aluminate $\ldots \ldots \ldots . . . . .475$

III. Summary

\section{INTRODUCTION}

The high-sulfate form of calcium sulfoaluminate, $3 \mathrm{CaO} . \mathrm{Al}_{2} \mathrm{O}_{3}$. $3 \mathrm{CaSO}_{4} \cdot 31 \mathrm{H}_{2} \mathrm{O}$, is a constituent of hydrated portland cement and is also produced by the action of sulfate waters on concrete [1]. ${ }^{1}$ Another compound, $3 \mathrm{CaO} . \mathrm{Al}_{2} \mathrm{O}_{3} . \mathrm{CaSO}_{4} \cdot 12 \mathrm{H}_{2} \mathrm{O}$, discovered by Lerch, Ashton, and Bogue [2], and known as the low-sulfate form of calcium sulfoaluminate, has not been identified in hydrated portland cement. Numerous other calcium aluminate complex salts have been synthesized in which the $\mathrm{SO}_{4}^{=}$radical of both the high- and low-sulfate forms is completely replaced by various acid radicals. A list of the compounds that have been prepared is given in table 1 .

\footnotetext{
1 Figures in brackets indicate literature references at the end of this paper.
} 
TABLE 1.-Calcium aluminate complex salts that have been synthesized by various investigators [3]

\begin{tabular}{|c|c|}
\hline Type I ${ }^{1}$ & Type II ${ }^{2}$ \\
\hline \multirow{8}{*}{ 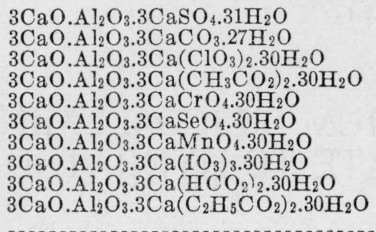 } & \multirow{8}{*}{$\begin{array}{l}3 \mathrm{CaO} \cdot \mathrm{Al}_{2} \mathrm{O}_{3} \cdot \mathrm{CaSO}_{4} \cdot 12 \mathrm{H}_{2} \mathrm{O} \\
3 \mathrm{CaO} \cdot \mathrm{Al}_{2} \mathrm{O}_{3} \cdot \mathrm{CaCO} \mathrm{Ca}_{3} \cdot 11 \mathrm{H}_{2} \mathrm{O} \\
3 \mathrm{CaO} \cdot \mathrm{Al}_{2} \mathrm{O}_{3} \cdot \mathrm{Ca}\left(\mathrm{ClO}_{3}\right)_{2} \cdot 10 \mathrm{H}_{2} \mathrm{O} \\
3 \mathrm{CaO} \cdot \mathrm{Al}_{2} \mathrm{O}_{3} \cdot \mathrm{Ca}\left(\mathrm{CH}_{3} \mathrm{CO}_{2}\right)_{2} \cdot 8 \mathrm{H}_{2} \mathrm{O}\end{array}$} \\
\hline & \\
\hline & \\
\hline & \\
\hline & \\
\hline & \\
\hline & \\
\hline & \\
\hline - & \multirow{4}{*}{$\begin{array}{l}3 \mathrm{CaO} \cdot \mathrm{Al}_{2} \mathrm{O}_{3} \cdot \mathrm{CaCl} \cdot 10 \mathrm{H}_{2} \mathrm{O} \\
3 \mathrm{CaO} \cdot \mathrm{Al}_{2} \mathrm{O}_{3} \cdot \mathrm{CaBr} \mathrm{Ca}_{2} \cdot 10 \mathrm{H}_{2} \mathrm{O} \\
3 \mathrm{CaO} \cdot \mathrm{Al}_{2} \mathrm{O}_{3} \cdot \mathrm{CaI} \mathrm{CH}_{2} \mathrm{O} \\
3 \mathrm{CaO} \cdot \mathrm{Al}_{2} \mathrm{O}_{3} \cdot \mathrm{Ca}\left(\mathrm{NO}_{3}\right)_{2} \cdot 10 \mathrm{H}_{2} \mathrm{O} \\
3 \mathrm{CaO} \cdot \mathrm{Al}_{2} \mathrm{O}_{3} \cdot \mathrm{Ca}\left(\mathrm{NO}_{2}\right)_{2} \cdot 10 \mathrm{H}_{2} \mathrm{O}\end{array}$} \\
\hline (n) & \\
\hline 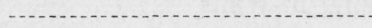 & \\
\hline$-1 n^{2}$ & \\
\hline
\end{tabular}

1 General formula: $3 \mathrm{CaO} . \mathrm{Al}_{2} \mathrm{O}_{3} \cdot 3 \mathrm{CaX} .30-32 \mathrm{H}_{2} \mathrm{O}$ or $3 \mathrm{CaO} . \mathrm{Al}_{2} \mathrm{O}_{3} \cdot 3 \mathrm{Ca} Y_{2} \cdot 30-32 \mathrm{H}_{2} \mathrm{O}$, where $X$ is a bivalent and $Y$ a univalent acid radical.

${ }_{2}^{2}$ General formula: $3 \mathrm{CaO} . \mathrm{Al}_{2} \mathrm{O}_{3} \cdot \mathrm{CaX} .8-12 \mathrm{H}_{2} \mathrm{O}$ or $3 \mathrm{CaO} . \mathrm{Al}_{2} \mathrm{O}_{3} \cdot \mathrm{Ca} Y_{2} .8-12 \mathrm{H}_{2} \mathrm{O}$, where $X$ is a bivalent, and $Y$ a univalent acid radical.

In spite of the fact that silica is the most abundant acidic oxide in portland cement, no previous attempts have been made to prepare the analogs of the calcium sulfoaluminates which would contain the silicic acid radical, $\mathrm{SiO}_{\overline{3}}^{\overline{2}}$. The present paper is a preliminary report on attempts to synthesize such compounds and also to obtain a replacement of $\mathrm{CaSO}_{4}$ in the high-sulfate calcium sulfoaluminate by $\mathrm{Ca}(\mathrm{OH})_{2}$. The data are presented at this time because it is anticipated that the completion of a more extensive study of these compounds may be somewhat delayed.

\section{EXPERIMENTAL PROCEDURE AND RESULTS}

\section{PREPARATION OF HYDRATED CALCIUM SILICOALUMINATES}

The silicoaluminate precipitates were made by a modification of a method that has been commonly used in preparing other complex salts of the calcium aluminates. This method consisted in mixing solutions of calcium silicate and aluminate in the desired proportions and in adding various amounts of solid calcium oxide.

A 20-liter volume of calcium silicate solution was prepared, according to a method described previously [4], by boiling purified silica gel with dilute calcium hydroxide solution $(0.1 \mathrm{~g}$ of $\mathrm{CaO}$ per liter) for about 18 hours and removing the undissolved residue by filtration. The filtrate contained $0.0303 \mathrm{~g}$ of $\mathrm{CaO}$ and $0.387 \mathrm{~g}$ of $\mathrm{SiO}_{2}$ per liter. A quantity of calcium aluminate extract was obtained by shaking $200 \mathrm{~g}$ of low-sulfate calcium aluminate cement $\left(0.03\right.$ per cent of $\left.\mathrm{SO}_{3}\right)$ with 4 liters of distilled water for 3 hours, filtering, and diluting the extract to 12 liters. The resulting solution contained $0.400 \mathrm{~g}$ of $\mathrm{CaO}$ and $0.581 \mathrm{~g}$ of $\mathrm{Al}_{2} \mathrm{O}_{3}$ per liter. ${ }^{2}$

\footnotetext{
2 It has been shown [9] that calcium aluminate solutions prepared from commercial calcium aluminate cements are practically free of iron. More recent studies have revealed that the quantity of silica extracted is so small that for the purpose at hand it may be neglected. The concentration of alkalies in the solution should have been too low to be a factor of moment because: first, a low-alkali cement was used in their preparation; second, a very high water-cement ratio was maintained; and, third, the solutions were subsequently diluted.
} 
As shown in table 2, mixtures of the calcium aluminate and silicate solutions were prepared in which the molar ratios of silica to alumina varied between 1 and 4. Quantities of solid calcium oxide were then immediately added to the mixtures in amounts sufficient to saturate the solutions with calcium hydroxide $(1.15 \mathrm{~g}$ of $\mathrm{CaO}$ per liter) and in addition to provide molar ratios of total lime to alumina $\left(\mathrm{CaO} / \mathrm{Al}_{2} \mathrm{O}_{3}+\right.$ $\mathrm{CaSiO}_{3} / \mathrm{Al}_{2} \mathrm{O}_{3}$ ) varying between three and seven in the precipitates. The precipitate in experiment 1, table 2, had the typical "silken" appearance of suspensions of the hexagonal hydrated calcium aluminates. This characteristic was exhibited in diminishing degree by the precipitates in experiments 2,3 , and 4 and not at all by those in experiments 5 and 6 . The mixtures, in well-stoppered flasks, were shaken for 15 minutes to disperse the added lime and thereafter at hourly intervals during the first day. The flasks were stored in the laboratory and subsequently shaken once daily in the course of the first month, after which they were allowed to stand without shaking. Samples of the precipitates were withdrawn at intervals for microscopical examination.

TABLE 2.-Preparation of hydrated calcium silicoaluminates

\begin{tabular}{|c|c|c|c|c|c|c|c|c|c|c|}
\hline \multirow{3}{*}{$\begin{array}{c}\text { Experi- } \\
\text { ment } \\
\text { number }\end{array}$} & \multicolumn{3}{|c|}{ Composition of mixture } & \multirow{3}{*}{$\begin{array}{l}\text { Elapsed } \\
\text { time } \\
\text { before } \\
\text { analysis } \\
\text { of sam- } \\
\text { ples of } \\
\text { precipi- } \\
\text { tate and } \\
\text { solution }\end{array}$} & \multicolumn{5}{|c|}{ Molar ratios in precipitate } & \multirow{3}{*}{$\begin{array}{l}\mathrm{CaO} \\
\text { con- } \\
\text { tent } \\
\text { of } \\
\text { solu- } \\
\text { tion }\end{array}$} \\
\hline & \multirow{2}{*}{$\begin{array}{l}\text { Calcium } \\
\text { alumi- } \\
\text { nate } \\
\text { solu- } \\
\text { tion } 1\end{array}$} & \multirow{2}{*}{$\begin{array}{l}\text { Calcium } \\
\text { silicate } \\
\text { solu- } \\
\text { tion }{ }^{2}\end{array}$} & \multirow[b]{2}{*}{$\begin{array}{l}\text { Solid } \\
\mathrm{CaO}\end{array}$} & & \multicolumn{2}{|c|}{ Calculated } & \multicolumn{3}{|c|}{ By analysis } & \\
\hline & & & & & $\frac{\mathrm{CaO}}{\mathrm{Al}_{2} \mathrm{O}_{3}}$ & $\frac{\mathrm{CaSiO}_{3}}{\mathrm{Al}_{2} \mathrm{O}_{3}}$ & $\frac{\mathrm{CaO}}{\mathrm{Al}_{2} \mathrm{O}_{3}}$ & $\frac{\mathrm{CaSiO}_{3}}{\mathrm{Al}_{2} \mathrm{O}_{3}}$ & $\frac{\mathrm{H}_{2} \mathrm{O}^{3}}{\mathrm{Al}_{2}}$ & \\
\hline & $\begin{array}{l}m l \\
2,000 \\
1,000 \\
1,000 \\
1,000 \\
1,000\end{array}$ & $\begin{array}{l}m l \\
1,769 \\
1,769 \\
1,769 \\
1,769 \\
2,654\end{array}$ & $\begin{array}{l}g \\
6.04 \\
3.69 \\
4.33 \\
4.65 \\
5.64\end{array}$ & $\begin{array}{r}\text { Days } \\
27 \\
60 \\
59 \\
60\end{array}$ & $\begin{array}{l}3 \\
1 \\
3 \\
4 \\
3\end{array}$ & $\begin{array}{l}1 \\
2 \\
2 \\
2 \\
3\end{array}$ & $\begin{array}{l}2.95 \\
2.00 \\
3.00 \\
3.70\end{array}$ & $\begin{array}{l}\text { 1. } 05 \\
\text { 2. } 09 \\
\text { 2. } 05 \\
\text { 2. } 15\end{array}$ & $\begin{array}{l}12.3 \\
12.3 \\
13.5 \\
14.8\end{array}$ & $\begin{array}{c}\text { g/liter } \\
1.14 \\
0.53 \\
1.11 \\
1.24\end{array}$ \\
\hline & 500 & 1,769 & 3.47 & 198 & 3 & 4 & 3.38 & 4. 27 & 19.2 & 1. 09 \\
\hline
\end{tabular}

1 Contained $0.581 \mathrm{~g}$ of $\mathrm{Al}_{2} \mathrm{O}_{3}, 0.400 \mathrm{~g}$ of $\mathrm{CaO}$ per liter.

2 Contained $0.387 \mathrm{~g}$ of $\mathrm{SiO}_{2}, 0.0303 \mathrm{~g}$ of $\mathrm{CaO}$ per liter.

3 Determined after washing precipitate with alcohol and ether, and drying to constant weight in a desiccator over calcium chloride.

The precipitate from experiment 1 became uniform in index of refraction within about 1 week. Although very finely divided, it appeared to be entirely composed of very small hexagonal plates, frequently occurring in spherulitic groups. The crystals are uniaxial negative and have the refractive indices, $\omega=1.538 \pm 0.003, \epsilon=1.523 \pm$ 0.003. Chemical analyses of the precipitate, after it had stood in contact with solution for 27 days, gave the molar ratios shown in table 2, which correspond to the formula $3 \mathrm{CaO} \cdot \mathrm{Al}_{2} \mathrm{O}_{3} \cdot \mathrm{CaSiO}_{3} \cdot 12 \mathrm{H}_{2} \mathrm{O}$. The X-ray diffraction pattern of the preparation is similar to those of $3 \mathrm{CaO} \cdot \mathrm{Al}_{2} \mathrm{O}_{3} \cdot \mathrm{CaSO}_{4} \cdot 12 \mathrm{H}_{2} \mathrm{O}$ and of $4 \mathrm{CaO} \cdot \mathrm{Al}_{2} \mathrm{O}_{3} \cdot 13 \mathrm{H}_{2} \mathrm{O}$ (or $3 \mathrm{CaO}$.$\mathrm{Al}_{2} \mathrm{O}_{3} . \mathrm{Ca}(\mathrm{OH})_{2} .12 \mathrm{H}_{2} \mathrm{O}$ ), with a closer relationship to $4 \mathrm{CaO} \cdot \mathrm{Al}_{2} \mathrm{O}_{3}$.$13 \mathrm{H}_{2} \mathrm{O}$.

In experiment 2 , table 2 , the preparation which contained $\mathrm{CaO}$, $\mathrm{Al}_{2} \mathrm{O}_{3}$, and $\mathrm{CaSiO}_{3}$ in the molar ratios 1:1:2 took up lime from solution and gave molar ratios of 2:1:2 in the precipitate. The molar ratios of the other analyzed precipitates agreed approximately with the calculated values. All of the preparations listed in table 2, except that 
of experiment 1, contained considerable finely divided or amorphous material as well as hexagonal plate crystals having the optical properties of $3 \mathrm{CaO} \cdot \mathrm{Al}_{2} \mathrm{O}_{3} \cdot \mathrm{CaSiO}_{3} \cdot 12 \mathrm{H}_{2} \mathrm{O}$. Their X-ray diffraction patterns corresponded with that of this compound. It was concluded, therefore, that the only silicoaluminate formed in these mixtures is the compound $3 \mathrm{CaO} \cdot \mathrm{Al}_{2} \mathrm{O}_{3} \cdot \mathrm{CaSiO}_{3} \cdot 12 \mathrm{H}_{2} \mathrm{O}$.

After these determinations, the mixtures were allowed to stand for an additional 3 years and samples of the precipitates were again withdrawn for microscopical examinations. A new phase was then observed in the precipitates. It appeared usually as long, thin, needlelike prisms. In some preparations where the crystals had a greater width, the prisms appeared to possess a hexagonal crosssection. They are uniaxial negative, $\omega=1.487 \pm 0.003, \epsilon=1.479 \pm$ 0.003. The crystals have parallel extinction and negative elongation.

Table 3 shows the approximate proportions of these crystals in the various precipitates. In each precipitate the more abundant phase consisted of the hexagonal plate form of silicoaluminate. No isometric crystals were found, thus indicating the absence of members of the garnet-hydrogarnet series [10].

TABLE 3.-Formation of needle crystals of calcium silicoaluminate in preparations of table 2, after standing for 3 years in contact with lime solutions

\begin{tabular}{|c|c|c|c|c|}
\hline \multirow{2}{*}{$\begin{array}{c}\text { Experiment } \\
\text { number }\end{array}$} & \multicolumn{2}{|c|}{$\begin{array}{c}\text { Approximate molar } \\
\text { ratios in precipitate }\end{array}$} & $\begin{array}{c}\text { Approximate } \\
\text { proportion } \\
\text { of needle } \\
\text { erystals in } \\
\text { precipitate }\end{array}$ & $\begin{array}{c}\text { CaO in } \\
\text { solution }\end{array}$ \\
\cline { 2 - 4 } & $\frac{\mathrm{CaO}}{\mathrm{A}_{2} \mathrm{O}_{3}}$ & $\frac{\mathrm{CaSiO}_{8}}{\mathrm{Al}_{2} \mathrm{O}_{8}}$ & & \\
\hline & & & $\%$ & g/liter \\
& 3 & 1 & 20 & 0.530 \\
& 1 & 2 & 30 & .344 \\
3 & 3 & 2 & 40 & .832 \\
4 & 2 & 40 & .905 \\
6 & 3 & 3 & 40 & .663 \\
& 3 & 4 & 5 & .541 \\
\hline
\end{tabular}

The needle crystals are believed to be a high-silica calcium silicoaluminate, $3 \mathrm{CaO} \cdot \mathrm{Al}_{2} \mathrm{O}_{3} \cdot 3 \mathrm{CaSiO}_{3} \cdot \mathrm{XH}_{2} \mathrm{O}$. The habit of these crystals and the measured optical properties, except indices of refraction, are identical with those of the high-sulfate calcium sulfoaluminate, $3 \mathrm{CaO} \cdot \mathrm{Al}_{2} \mathrm{O}_{3} \cdot 3 \mathrm{CaSO}_{4} \cdot 31 \mathrm{H}_{2} \mathrm{O}$. A water content of 30 to 32 moles is tentatively assigned to the silicate compound by analogy with the various similar calcium aluminate complex salts which have been prepared.

The behavior of the low-silica form of calcium silicoaluminate in converting slowly to the high-silica form is entirely similar to the relations exhibited by the calcium sulfoaluminates. Thus, in the preparation of the high-sulfate calcium sulfoaluminate, Lerch, Ashton, and Bogue [2] observed that the low-sulfate compound was usually obtained as an intermediate product, despite the presence of an excess of $\mathrm{CaSO}_{4}$. The conversion to the more stable sulfoaluminate is usually complete in about a week, whereas the corresponding transformation, in the case of the silicoaluminate compounds, is incomplete after 3 years, even in experiment 5 , where $\mathrm{CaO}, \mathrm{Al}_{2} \mathrm{O}_{3}$, and $\mathrm{SiO}_{2}$ were in the proper proportions to form the high-silica product. 
The precipitates in experiments 4 and 5 of table 3 gave the $\mathrm{X}$-ray diffraction pattern of $3 \mathrm{CaO} \cdot \mathrm{Al}_{2} \mathrm{O}_{3} \cdot \mathrm{CaSiO}_{3} \cdot 12 \mathrm{H}_{2} \mathrm{O}$, together with additional lines. Because of the obscuring effect of the stronger pattern it was not possible to determine whether these additional lines indicated an X-ray diffraction pattern similar to that of the high-sulfate calcium sulfoaluminate.

The lime contents of the solutions after 3 years' contact with the silicoaluminate precipitates are shown in the last column of table 3 . These values indicate that the high-silica calcium silicoaluminate will form in the presence of solutions containing between 0.3 and $0.9 \mathrm{~g}$ of $\mathrm{CaO}$ per liter.

\section{FORMATION OF HIGH-SILICA CALCIUM SILICOALUMINATE FROM MIXTURES OF CEMENT COMPOUNDS}

In order to determine if hydrated calcium silicoaluminate will form from mixtures of the various cement compounds in saturated lime solution, the combinations of anhydrous calcium aluminates and silicates shown in table 4 were prepared. The mixtures, which contained the compounds in equimolar proportions, were added to 1-liter portions of saturated lime solution (1.15 $\mathrm{g}$ of $\mathrm{CaO}$ per liter) and placed in tightly stoppered flasks, which were allowed to stand for 3 years with occasional shaking. Samples were then withdrawn for microscopical examination.

TABLE 4.-Formation of needle crystals of calcium silicoaluminate in mixtures of cement compounds placed in saturated lime solution (1.15 g CaO per liter) and allowed to stand for 3 years

\begin{tabular}{|c|c|c|c|c|}
\hline $\begin{array}{l}\text { Experiment } \\
\text { number }\end{array}$ & Mixture 1 & $\begin{array}{l}\text { Weight of } \\
\text { mixture per } \\
\text { volume of } \\
\text { lime solution }\end{array}$ & $\begin{array}{l}\text { Approximate } \\
\text { proportion of } \\
\text { needle form of } \\
\text { silicoaluminate } \\
\text { in product }\end{array}$ & $\begin{array}{l}\mathrm{CaO} \text { in } \\
\text { solution }\end{array}$ \\
\hline 1 & $\begin{array}{l}\beta-2 \mathrm{CaO} \cdot \mathrm{SiO}_{2}+4 \mathrm{CaO} \cdot \mathrm{Al}_{2} \mathrm{O}_{3} \cdot \mathrm{Fe}_{2} \mathrm{O}_{3} \\
\beta-2 \mathrm{CaO} \cdot \mathrm{SiO}_{2}+3 \mathrm{CaO} \cdot \mathrm{Al}_{2} \mathrm{O}_{3} \\
\text { 3CaO.SiO} \\
\text { 3CaO. } \mathrm{SiO}_{2}+3 \mathrm{CaO} \cdot \mathrm{Al}_{2} \mathrm{O}_{3} \cdot \mathrm{Fe}_{2} \mathrm{O}_{3}\end{array}$ & g/liter $\begin{array}{r} \\
18 \\
10 \\
10 \\
10\end{array}$ & $\begin{array}{r}\% \\
10 \\
30 \\
15 \\
0\end{array}$ & $\begin{array}{r}\text { g/liter } \\
1.02 \\
1.11 \\
1.08 \\
1.15\end{array}$ \\
\hline
\end{tabular}

1 The mixtures contained equimolar proportions of the compounds.

As shown in table 4, all of the products, except that from the mixture of tricalcium aluminate and tricalcium silicate, contained appreciable amounts of the high-silica calcium silicoaluminate, which appeared as well-developed needle-like prisms. Hexagonal plate crystals were also present in the materials. No attempt was made to identify the crystalline phases which made up the balance of the products.

The lime contents of the solutions given in the last column of table 4 , in conjunction with similar data in table 3 , indicate that the highsilica silicoaluminate can form in contact with solutions containing calcium hydroxide in amounts between $0.3 \mathrm{~g}$ of $\mathrm{CaO}$ per liter and saturation.

\section{PREPARATION OF HYDRATED HEXACALCIUM ALUMINATE}

Assarsson [5] observed the precipitation of needle-shaped hexagonal prisms from extracts of monocalcium aluminate and high-alumina cements. He assigned to this material the formula $5 \mathrm{CaO} \cdot \mathrm{Al}_{2} \mathrm{O}_{3} \cdot 34 \mathrm{H}_{2} \mathrm{O}$, 
but stated, in his discussion of a paper by Bessey [6], that it seems to be impossible to prepare the compound without any trace of sulfate. Wells, Clarke, and McMurdie [7] failed to find such an aluminate in the system $\mathrm{CaO}-\mathrm{Al}_{2} \mathrm{O}_{3}-\mathrm{H}_{2} \mathrm{O}$ at $21^{\circ}$ and $90^{\circ} \mathrm{C}$, and suggested that it may exist in the quaternary system $\mathrm{CaO}-\mathrm{Al}_{2} \mathrm{O}_{3}-\mathrm{CaSO}_{4}-\mathrm{H}_{2} \mathrm{O}$ as a metastable phase. Bessey [6] expressed the opinion that the compound may be related in structure to the high-sulfate form of calcium sulfoaluminate.

The preparation of such an aluminate was attempted in order to determine if the calcium sulfate in $3 \mathrm{CaO} \cdot \mathrm{Al}_{2} \mathrm{O}_{3} \cdot 3 \mathrm{CaSO}_{4} \cdot 31 \mathrm{H}_{2} \mathrm{O}$ can be completely replaced by calcium hydroxide. It was anticipated that the highly basic compound which might result from such replacement would only be stable in contact with solutions containing high concentrations of calcium hydroxide.

Accordingly, an excess of calcium oxide was added to $500 \mathrm{ml}$ of a 10-percent sugar solution, the mixture shaken for 3 hours, and filtered. The filtrate contained $17 \mathrm{~g}$ of $\mathrm{CaO}$ per liter. A calcium aluminate extract was prepared by shaking $50 \mathrm{~g}$ of calcium aluminate cement (containing 0.03 percent of $\mathrm{SO}_{3}$ ) with $500 \mathrm{ml}$ of water for 3 hours and filtering. This extract contained $1.8 \mathrm{~g}$ of $\mathrm{Al}_{2} \mathrm{O}_{3}$ and $1.2 \mathrm{~g}$ of $\mathrm{CaO}$ per liter. The solutions were mixed and allowed to stand. Formation of a precipitate began within a few hours. After 5 days, samples of the precipitate and solution were withdrawn. Titration of the solution with standard acid showed a lime content of $9.06 \mathrm{~g}$ of $\mathrm{CaO}$ per liter. The sample of precipitate was placed in a flask with $100 \mathrm{ml}$ of absolute alcohol and the mixture shaken for 1 hour to remove any sugar from mother liquor adhering to the particles. The solid material was then filtered off, washed with alcohol and ether, and dried in air overnight.

Microscopical examination showed that the preparation consisted of needle-like prisms entirely similar in appearance to crystals of the high-sulfate form of calcium sulfoaluminate. The crystals are uniaxial negative; $\omega=1.475 \pm 0.003$ and $\epsilon=1.466 \pm 0.003$. They have parallel extinction and negative elongation.

Analysis of the preparation gave the following composition:

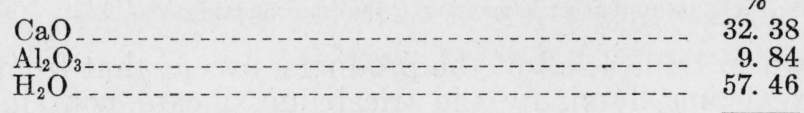

Total.

99. 68

This corresponds to molar ratios of $5.98 \mathrm{CaO}: 1 \mathrm{Al}_{2} \mathrm{O}_{3}: 33 \mathrm{H}_{2} \mathrm{O}$. Accordingly, the compound may be assigned the formula, $6 \mathrm{CaO} \cdot \mathrm{Al}_{2} \mathrm{O}_{3}$. $33 \mathrm{H}_{2} \mathrm{O}$ or $3 \mathrm{CaO} \cdot \mathrm{Al}_{2} \mathrm{O}_{3} \cdot 3 \mathrm{Ca}(\mathrm{OH})_{2} \cdot 30 \mathrm{H}_{2} \mathrm{O}$. Its X-ray diffraction pattern is almost indistinguishable from that of $3 \mathrm{CaO} \cdot \mathrm{Al}_{2} \mathrm{O}_{3} \cdot 3 \mathrm{CaSO}_{4} \cdot 31 \mathrm{H}_{2} \mathrm{O}$.

It is believed that this compound and Assarsson's pentacalcium aluminate hydrate are fundamentally the same and that the lower $\mathrm{CaO} / \mathrm{Al}_{2} \mathrm{O}_{3}$ ratio of Assarsson's compound is caused by partial hydrolysis.

Although qualitative tests of the $3 \mathrm{CaO} \cdot \mathrm{Al}_{2} \mathrm{O}_{3} \cdot 3 \mathrm{Ca}(\mathrm{OH})_{2} \cdot 30 \mathrm{H}_{2} \mathrm{O}$ indicated the absence of sulfate, it seemed desirable to prepare it from starting materials in which this constituent was entirely absent. 
Accordingly, a calcium aluminate extract was made from sulfate-free $3 \mathrm{CaO} .5 \mathrm{Al}_{2} \mathrm{O}_{3}$ and added to a lime-sugar solution prepared as before. The resulting crystalline precipitate was identical in all respects with that which resulted from mixing the extract of calcium aluminate cement with lime-sugar solution.

\section{SUMMARY}

Two calcium silicoaluminates, apparently analogs of the high- and low-sulfate forms of calcium sulfoaluminate, were investigated. The low-silica silicoaluminate has the formula, $3 \mathrm{CaO} \cdot \mathrm{Al}_{2} \mathrm{O}_{3} \cdot \mathrm{CaSiO}_{3} \cdot 12 \mathrm{H}_{2} \mathrm{O}$, and occurs as thin hexagonal plates. In contact with lime solutions, it is slowly converted to long needle-like prisms whose habit and optical properties are very similar to those of $3 \mathrm{CaO} \cdot \mathrm{Al}_{2} \mathrm{O}_{3} \cdot 3 \mathrm{CaSO}_{4} \cdot 31 \mathrm{H}_{2} \mathrm{O}$. The needle-form of the silicoaluminate has not yet been prepared in a pure state but, by analogy with other similar calcium aluminate complex salts, it has tentatively been assigned the formula, $3 \mathrm{CaO}$. $\mathrm{Al}_{2} \mathrm{O}_{3} \cdot 3 \mathrm{CaSiO}_{3} \cdot 30-32 \mathrm{H}_{2} \mathrm{O}$. It was also found in the following mixtures of cement compounds, which had stood in contact with approximately saturated lime solutions for 3 years: $\beta-2 \mathrm{CaO} \cdot \mathrm{SiO}_{2}$ and $4 \mathrm{CaO} \cdot \mathrm{Al}_{2} \mathrm{O}_{3}$. $\mathrm{Fe}_{2} \mathrm{O}_{3} ; \beta-2 \mathrm{CaO} . \mathrm{SiO}_{2}$ and $3 \mathrm{CaO} \cdot \mathrm{Al}_{2} \mathrm{O}_{3}$; and $3 \mathrm{CaO} \cdot \mathrm{SiO}_{2}$ and $4 \mathrm{CaO}$. $\mathrm{Al}_{2} \mathrm{O}_{3} \cdot \mathrm{Fe}_{2} \mathrm{O}_{3}$. The role of the silicoaluminates in the setting and hardening of cements warrants further study. The close analogy between the silico- and sulfoaluminates suggests the possible existence of a solid-solution series between these compounds with the formation of sulfo-silicoaluminates, somewhat similar to those reported by Lafuma [8].

A hexacalcium aluminate hydrate was prepared that appears to be the analog of the high-sulfate form of calcium sulfoaluminate in which calcium sulfate is completely replaced by calcium hydroxide. Its formula may be written as $3 \mathrm{CaO} \cdot \mathrm{Al}_{2} \mathrm{O}_{3} \cdot 3 \mathrm{Ca}(\mathrm{OH})_{2} \cdot 30 \mathrm{H}_{2} \mathrm{O}$. This compound would probably not form as a direct hydration product of portland cement but might appear, under some conditions, as a solid solution in the high-sulfate form of calcium sulfoaluminate.

The authors are indebted to H. F. McMurdie for making the X-ray diffraction patterns of the preparations.

\section{REFERENCES}

[1] F. M. Lea and C. H. Desch, The Chemistry of Cement and Concrete, p. 155 (Longmans, Green \& Co., New York, N. Y., and Edwin Arnold \& Co., London, 1935).

[2] W. Lerch, F. W. Ashton, and R. H. Bogue, The sulfoaluminates of calcium, BS J. Research 2, 715-31 (1929) RP54.

[3] F. E. Jones, The calciumaluminate complex salts, Proc. Symposium on Chem. of Cements, p. 231-45, Stockholm (1938).

[4] E. P. Flint and Lansing S. Wells, Study of the system $\mathrm{CaO}-\mathrm{SiO}_{2}-\mathrm{H}_{2} \mathrm{O}$ at $30^{\circ} \mathrm{C}$ and of the reaction of water on the anhydrous calcium silicates, BS J. Research 12, 751-83 (1934) RP687.

[5] Gunnar Assarsson, The reaction between alumina cement and water, Sveriges Geologiska undersökn. 27 [C] No. 379, 31 (1933).

[6] G. E. Bessey, The calcium aluminate and silicate hydrates, Proc. Symposium on Chem. of Cements, p. 178-230, Stockholm (1938). 
[7] Lansing S. Wells, W. F. Clarke, and H. F. McMurdie, Study of the system $\mathrm{CaO}-\mathrm{Al}_{2} \mathrm{O}_{3}-\mathrm{H}_{2} \mathrm{O}$ at temperatures of $21^{\circ}$ and $90^{\circ} \mathrm{C}$, J. Research NBS 30, 367-409 (1943) RP1539.

[8] H. Lafuma, The aluminates of calcium and the chemistry of cement. Researches on the aluminates of calcium and on their combination with the chloride and sulfate of calcium. (Extracts from the doctorate thesis of the author), Cement 30, 174-89 (1925). Also Dissertation, University of Paris, 1925.

[9] Lansing S. Wells, Reaction of water on calcium aluminates. BS J. Research 1, 976 (1928) RP34.

[10] E. P. Flint, Howard F. McMurdie, and Lansing S. Wells, Hydrothermal and $X$-ray studies of the garnet-hydrogarnet series and the relationship of the series to hydration products of portland cement, J. Research NBS 26, 13 (1941) RP1355.

Washington, September 19, 1944. 
NATIONAL BUREAU OF STANDARDS, WASHINGTON, D. C.

Send me the Mathematical Tables marked X below. I enclose remittance ${ }^{1}$ to cover the cost.

\begin{tabular}{|c|c|c|c|c|}
\hline Mark X & Title of publication & $\begin{array}{l}\text { United States and } \\
\text { its possessions, } \\
\text { and countries ex- } \\
\text { tending franking } \\
\text { privilege }\end{array}$ & Other countries & Amount enclosed \\
\hline (- & 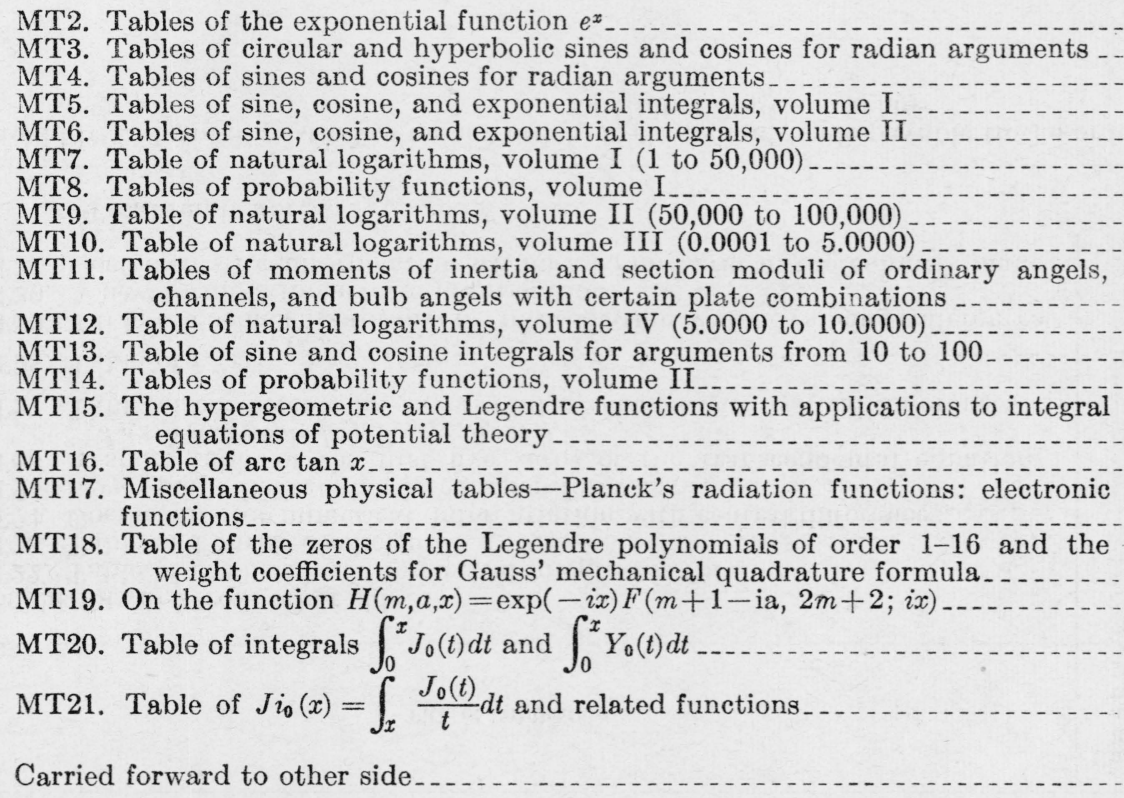 & $\begin{array}{r}\$ 2.00 \\
2.00 \\
2.00 \\
2.00 \\
2.00 \\
2.00 \\
2.00 \\
2.00 \\
2.00 \\
2.00 \\
2.00 \\
2.00 \\
2.00 \\
2.00 \\
2.00 \\
1.50 \\
\\
\\
\\
25 \\
.25\end{array}$ & $\begin{array}{r}\$ 2.50 \\
2.50 \\
2.50 \\
2.50 \\
2.50 \\
2.50 \\
2.50 \\
2.50 \\
2.50 \\
2.50 \\
2.50 \\
2.50 \\
2.50 \\
2.50 \\
2.50 \\
1.75 \\
\\
.30 \\
.30\end{array}$ & - \\
\hline
\end{tabular}




\begin{tabular}{|c|c|c|c|c|}
\hline Mark X & Title of Publication & $\begin{array}{l}\text { United States and } \\
\text { its possessions, } \\
\text { and countries ex- } \\
\text { tending franking } \\
\text { privilege }\end{array}$ & Other countries & Amount enclosed \\
\hline $\begin{array}{l}-1 \\
-1\end{array}$ & $\begin{array}{l}\text { Brought forward from other side } \\
\text { MT22. Table of coefficients in numerical integration formulation } \\
\text { MT23. Table of Fourier coefficients } \\
\text { MT24. Coefficients for numerical differentiation with central differences } \\
\text { MT25. Seven-point Lagrangian integration formulas } \\
\text { MT26. A short table of the first five zeros of the transcendental equation, } \\
\text { MT27. Table of coefficients for inverse interpolation with central differences } J_{0}(x) Y_{0}(k x)-J_{0}(k x) Y_{0}(x)=0 \\
\text { MT28. Table of } f_{n}(x)=\frac{n !}{(x / 2)} J_{n}(x) \\
\text { MT29. Table of coefficients for inverse interpolation with advancing differences } \\
\text { MT30. A new formula for inverse interpolation } \\
\text { MT31. Coefficients for interpolation within a square grid in the complex plane. }\end{array}$ & $\begin{array}{r}\$ 0.25 \\
.25 \\
.25 \\
.25 \\
.25 \\
.25 \\
.25 \\
.25 \\
.25 \\
.25\end{array}$ & $\begin{array}{r}\$ 0.30 \\
.30 \\
.30 \\
.30 \\
.30 \\
.30 \\
.30 \\
.30 \\
.30 \\
.30\end{array}$ & \begin{tabular}{|c|}
$\$$ \\
$\$$ \\
\hdashline
\end{tabular} \\
\hline
\end{tabular}

Remittance should be in form of post-office money order, or check, and made payable to the order of the "National Bureau of Standards" in United States currency

Send to

Number and Street

City, Zone, and State 


\section{MATHEMATICAL TABLES}

Attention is invited to a series of publications prepared by the Project for the Computation of Mathematical Tables conducted by the Pederal Works Agency, Work Projects Administration for the City of New York, under the sponsorship of the National Bureau of Standards. The tables which have been made available through the National Bureau of Standards are listed below. A list of other WPA tables obtainable elsewhere will be sent by the Bureau on request.

There is included in this list a publication on the hypergeometric and Legendre functions (MT15), prepared by the Bureau.

MT1. Table of the First Ten Powers or the Intbgers From 1 to 1000: (1938) VIII +80 pages; heavy paper cover. Out of print.

MT2. TABLis of ThB Expongntial Function $e^{x}$ : The ranges and intervals of the argument and the number of decimal places in the entries are given below:

$\begin{array}{ccc}\text { Range of } x & \text { Interval of } x & \text { Decimals given } \\ -2.5000 \text { to } 1.0000 & 0.0001 & 18 \\ 1.0000 \text { to } 2.5000 & .0001 & 15 \\ 2.500 \text { to } 5.000 & .001 & 15 \\ 5.00 \text { to } 10.00 & .01 & 12\end{array}$

(1939) XV +535 pages; bound in buckram, $\$ 2.00$.

MT3. Tables of Circular and Hyprrbolic Sings and Cosings for Radian Arguments: Con. tains 9 decimal place values of $\sin x, \cos x, \sinh x$, and $\cosh x$ for $x$ (in radians) ranging Ifrom 0 to 2 at intervals of 0.0001 . (1939) XVII + 405 pages; bound in buckram, $\$ 2.00$.

MT4. Tables or Sines and Cosings for Radian Arguments:Contains 8 decimal place values" of sines and cosines for radian arguments ranging from 0 to 25 at intervals of 0.001 . (1940) XXIX +275 pages; bound in buckram, $\$ 2.00$.

MT5. Tables of Sine, Cosine, and Exponential Intrgrals, Volume I: Values of these functions to 9 places of decimals from 0 to 2 at intervals of 0.0001 . (1940) XXVI +444 pages; bound in buckram, $\$ 2.00$.

MT6. TAbles of Sine, Cosing, AND Exponential Intrgrals, Volumb II: Values of these functions to 9,10 , or 11 significant figures from 0 to 10 at intervals of 0.001 with auxiliary tables. (1940) XXXVII + 225 pages; bound in buckram, $\$ 2.00$.

MT7. TABle of Natural Logarithms, Volume I: Logarithms of the integers from 1 to 50,000 to 16 places of decimals. (1941) XVIII + 501 pages; bound in buckram, $\$ 2.00$.

MT8. Tablbs of Probability Functions, Volume I: Values of these functions to 15 places of decimals from 0 to 1 at intervals of 0.0001 and from 1 to 5.6 at intervals of 0.001 . (1941) XXVIII + 302 pages; bound in buckram, $\$ 2.00$.

MT9. Table op Natural Logarithms, Volumb II: Logarithms of the integers from 50,000 to 100,000 to 16 places of decimals. (1941) XVIII +501 pages; bound in buckram, $\$ 2.00$.

MT10. Table or NatURAL Logarithm, Volumb III: Logarithms of the decimal numbers from 0.0001 to 5.0000 , to 16 places of decimals. (1941) XVIII +501 pages; bound in buckram, $\$ 2.00$.

MT11. Tables of thr Moments or Intrtia and Section Moduli of Ordinary Angles, Chan, nels, and Bulb Angles with Certain Platb Combinations: (1941) XIII + 197 pages; bound in green cloth. $\$ 2.00$.

MT12. Table of Natural Logarithms, Volume IV: Logarithms of the decimal numbers from 5.0000 to 10.0000 , to 16 places of decimals. (1941) XXII +506 pages; bound in buckram, $\$ 2.00$.

MT13. T able or Sine and Cosine Integrals for Arguments prom 10 to 100: (1942) XXXII +185 pages; bound in buckram, $\$ 2.00$.

MT14. Tables of Probabiltry Functions, Volume II: Values of these functions to 15 places of decimals from 0 to 1 at intervals of 0.0001 and from 1 to 7.8 at intervals of 0.001 . (1942) XXI +344 pages; bound in buckram, $\$ 2.00$.

MT15. The Hypergeometric and Legrndre Functions With Applications to Intrgral Equa. tions of Potential Theory. By Chester Snow, National Bureau of Standards. Reproduced from original handwritten manuscript. (1942) VII +319 pages, bound in heavy paper cover $\$ 2.00$.

MT16. TABLE OP ARC $T_{\text {AN }} x$ : Table of inverse tangents for positive values of the angle in radians, Second central differences are included for all entries. $x=\llbracket 0(.001) 7(.01) 50(.1) 300(1) 2,000(10)$ 10,$000 ; 12 D \rrbracket$ (1942) XXV + 169 pages; bound in buckram, $\$ 2.00$.

[Continued on p. 4 of cover] 


\section{【Continued from p. 3 of cover】}

MT17. Mrscrllaneous Physical Tables: Planck's Radiation Functions (Originally published in the Journal of the Optical Society of America, February 1940); and Errctronic Functions. (1941) VII + 58 pages; bound in buckram, $\$ 1.50$.

MT18. Table of the Zero8 of the Legendre Polynomials of Order 1-16 and the Weight Corficients for Gauss' Mechanical Quadrature Formula. (Reprinted from Bul. Amer. Mathematical Society, October 1942.) 5 pages, with cover, 25 cents.

MT19. On the Function $H(m, a, x)=\operatorname{Exp}(-i x) F(m+1-i a, 2 m+2 ; i x)$; with table of the confluent hypergeometric function and its first derivative. (Reprinted from J. Math. Phys., December 1942.) 20 pages, with cover, 25 cents.

MT20. TABLE of Integrals $\int_{0}^{x} J_{0}(t) d t$ and $\int_{0}^{x} Y_{0}(t) d t$. (Reprinted from J. Math. Phys., May 1943.) 12 pages, with cover, 25 cents.

MT21. TABle of Jio $(x)=\int_{x}^{\infty} \frac{J_{0}(t)}{t} d t$ and Related Functions. (Reprinted from J. Math. Phys., June 1943.) 7 pages, with cover, 25 cents.

MT22. Table of Cotpricients in Numerical Intrgration Formulat. (Reprinted from J. Math. Phys., June 1943.) 2 pages, with cover, 25 cents.

MT23. Tablz of Fourier Corppicients. (Reprinted from J. Math. Phys. Sept. 1943.) 11 pages, with cover, 25 cents.

MT24. Compricient8 for Numerical Differentiation With Central Difrerences. (Reprinted from J. Math. Phys., Sept. 1943) 21 pages, with cover, 25 cents.

MT25. Seven-Point Lagrangian Integration Formulas. (Reprinted from J. Math. Phys., Dec. 1943.) 4 pages, with cover, 25 cents.

MT26. A Short Table of the Frrst Five Zeros of thr Transcendental Equation $J_{0}(x) Y_{0}(k x)-J_{0}(k x) Y_{0}(x)=0$. (Reprinted from J. Math. Phys., Dec. 1943.) 2 pages, with cover, 25 cents.

MT27. Table of Coepricients for Inverse Interpolation with Central Diprerences; (Reprinted from J. Math. Phys., Dec. 1943.) 15 pages, with cover, 25 cents.

MT28. TABLE OR $f_{m}(x)=\frac{n !}{(x I / 2)^{n}} J_{m}(x)$. (Reprinted from J.inath. Phys., JFeb. 1944.) 16 pages, with cover, 25 cents.

MT29. Table of Cobpfictents for Inverse Interpolation with Advancing Dipfrerences. (Reprinted from J. Math. Phys., May 1944.) 28 pages, with cover, 25 cents.

MT30. A New Formula for Inverse Interpolation. (Reprinted from Bul. Amer. Mathe matical Society, Aug. 1944.) 4 pages, with cover, 25 cents.

mT31. Cobpricients for Interpolation Within a Square Grid in the Complex Plane. (Reprinted from J. Math. Phys., Aug. 1944). 11 pages, with cover, 25 cents.

Payment is required in advance. Make remittance payable to the "National Bureau of Standards" and send with order, using the blank form facing page 3 of the cover.

A mailing list is maintained for those who desire to receive announcements regarding new tables as they become available. 